\title{
Interactions Between Fibroblast Cells and Laser Beam Welded AISI 2205 Duplex Stainless Steel
}

\author{
Ceyhun KÖSE ${ }^{1 *}$, Ramazan KAÇAR ${ }^{2}$, Aslı Pınar ZORBA ${ }^{3,4}$, Melahat BAĞIROVA ${ }^{3}$, \\ Emrah Şefik ABAMOR ${ }^{3}$, Adil M. ALLAHVERDİYEV ${ }^{3}$
}

\author{
${ }^{1}$ Faculty of Natural Sciences and Engineering, Department of Mechanical Engineering, Gaziosmanpaşa University, Tokat, \\ Turkey \\ ${ }^{2}$ Faculty of Technology, Department of Manufacturing Engineering, Karabük University, Karabük, 78050, Turkey \\ ${ }^{3}$ Department of Bioengineering Cell Culture and Tissue Engineering, Yıldiz Technical University, Istanbul, Turkey \\ ${ }^{4}$ Vocational School of Health Services, Bilgi University, Istanbul, Turkey
}

crossref http://dx.doi.org/10.5755/j01.ms.24.2.18006

Received 20 April 2017; accepted 19 July 2017

\begin{abstract}
Because of their high mechanical strength, excellent corrosion resistance and good weldability, duplex stainless steels are mostly used in industries such as oil, chemistry, petrochemistry, food and occasionally used in medical industry. These properties have enabled us to use duplex stainless steels in biomedical applications recently. Accordingly, duplex stainless steel material can be highly important to examine the toxic effect on the cells. In this study, the effect of the AISI 2205 duplex stainless steels which are joined by $\mathrm{CO}_{2}$ laser beam welding on viability of $\mathrm{L} 929$ fibroblast cells has been studied in vitro for the first time. For this aim, the cells were kept in DMEM/F-12 (Thermofisher Scientific 31331-028) medium for 7 days. The viability study was experimentally studied using the MTT (Thiazolyl Blue Tetrazolium Bromide) method for 7 days. The cell viability of the laser beam welded sample has been detected to be higher than that of the base metal and the control based on 7th day data. According to the obtained results, it was revealed that laser beam welded and base metal AISI 2205 duplex stainless steel has been found suitable to study for biomedical applications.

Keywords: laser beam welding, duplex stainless steel, L929 fibroblast cell, viability, microstructure.
\end{abstract}

\section{INTRODUCTION}

Duplex stainless steels (DSSs) consist of a two phase microstructure involving ferrite and austenite. DSS as suitable alternatives to conventional austenitic stainless steels. Duplex stainless steel shows such excellent mechanical properties and corrosion resistance due to the fact that its internal structure consists of ferrite and austenite phases at equal rates [1-3]. The duplex microstructure enables the steel to become especially highly resistant to stress corrosion cracking as well as intergranular and pitting corrosion. AISI 2205 stainless steel, with $22 \%$ chromium, $5-6 \%$ nickel, and $3 \%$ molybdenum, is a nitrogen-alloyed duplex stainless steel with excellent corrosion resistance and mechanical properties. Due to its superior corrosion resistance, this type of steel is used in steam boilers, chemical tanks and heat exchanger pipes as well as in a wide range of areas in the chemical and petroleum chemical industry and less in the medical industry [4-6]. Weldability of duplex stainless steel is very good and it can be joined by many fusion welding techniques, such as submerged arc welding (SAW), shielded metal arc welding (SMAW) and tungsten inert gas welding (TIG) and laser beam welding [7]. $\mathrm{CO}_{2}$ laser beam welding method compare with the other conventional welding methods from many aspects such as low heat input, high concentration energy, high welding

\footnotetext{
* Corresponding author. Tel: +90 35625218 00; Fax: +90 3562521729 , E-mail adress: ceyhun.kose@gop.edu.tr (C. Köse)
}

speed, narrow weld zone, deep penetration, low distortion, high mechanical strength [8-16].

AISI 316L austenitic stainless steel is known as the most commonly used orthopaedic and orthodontic bracket material because of its favourable mechanical properties, and relatively good corrosion resistance in various aqueous environments [17]. However, it is regularly challenged by the aggressive environment in the human body, as it is highly susceptible to localized corrosion in environments containing chloride $[17,18]$. Therefore, austenitic stainless steels are currently often replaced with duplex stainless steels, such as AISI 2205 duplex stainless steel. Recent studies have shown that because of high mechanical strength and excellent corrosion resistance properties of duplex stainless steels, these materials can be an alternative to biomaterials AISI 316L, titanium and its alloys [19-21].

There are many studies on the laser beam welding process of AISI 2205 duplex stainless steel [16, 17, 22-24]. L929 fibroblast cells are an internationally accepted cell line derived from mice and immortalized and routinely used in biocompatibility and cytotoxic evaluations [25]. However, there is no study regarding investigation of in vitro relation between laser beam welded AISI 2205 duplex stainless steel and fibroblast cells in the literature. Welded implants' and prosthesis' biological properties such as biocompatibility and cell toxicity should be examined under in vitro conditions prior to its clinical application. The effects of the 
AISI 2205 duplex stainless steels which are joined by $\mathrm{CO}_{2}$ laser beam welding method on the fibroblast cells has been studied in vitro for the first time with this study.

\section{EXPERIMENTAL PROCEDURE}

\subsection{Material, welding process, surface analysis and the preparation of test specimen}

In this study, AISI 2205 duplex stainless steel, of which the chemical composition (wt.\%) that is achieved with spectral analysis method is provided in Table 1, has been used.

Table 1. The chemical composition of AISI 2205 stainless steel, wt. $\%$

\begin{tabular}{|c|c|c|c|c|}
\hline $\mathrm{C}$ & $\mathrm{Si}$ & $\mathrm{Mn}$ & $\mathrm{P}$ & $\mathrm{S}$ \\
0.028 & 0.333 & 1.814 & 0.011 & 0.0072 \\
\hline $\mathrm{Cr}$ & $\mathrm{Mo}$ & $\mathrm{Ni}$ & $\mathrm{Al}$ & $\mathrm{Co}$ \\
22.88 & 3.105 & 5.450 & 0.019 & 0.119 \\
\hline $\mathrm{Cu}$ & $\mathrm{Nb}$ & $\mathrm{Ti}$ & $\mathrm{V}$ & $\mathrm{W}$ \\
0.224 & 0.036 & 0.0089 & 0.116 & 0.050 \\
\hline $\mathrm{Pb}$ & $\mathrm{Sn}$ & $\mathrm{Zn}$ & $\mathrm{N}$ & $\mathrm{Fe}$ \\
0.0038 & 0.012 & 0.034 & 0.058 & 65.68 \\
\hline
\end{tabular}

AISI 2205 duplex stainless steel plates were joined in butt position without any need to filler metal by being attached to a pre-prepared fixture mold and in flat position by means of a $4 \mathrm{~kW}$ Trumpf Lasercell $1005 \mathrm{CO}_{2}$ laser beam welding machine with $4000 \mathrm{~W}$ laser power, $270 \mathrm{~cm} / \mathrm{min}$ travel speed, $200 \mathrm{~mm}$ focal length, gas flow rate of 10 liters per minute, $50 \% \mathrm{Ar}+50 \% \mathrm{He}$ shielding gas and $0.088 \mathrm{~kJ} / \mathrm{mm}$ heat input. Samples have been polished by $200-1200$ grit emery paper after being cut in sizes of $3 \times 5 \times 20 \mathrm{~mm}$ and perpendicular to the welding direction so that the welding seam is left in the middle. The process of electrolytic etching was applied using a solution of $10 \mathrm{~g}$ oxalic acid $+100 \mathrm{ml}$ pure $\mathrm{H}_{2} \mathrm{O}$. Microstructure examinations were carried out by using optical microscope (OLYMPUS) at magnifications between $5 \times-100 \times$, JEOL JSM 6060 LV brand SEM and EDS. XRD analysis was performed using RIGAKU DMAX-2200/PC at a voltage rating of $40 \mathrm{kV}$ voltage rating and $40 \mathrm{~mA}$ current with a scan rate of $2 \% \mathrm{~min}$. by employing $\mathrm{Cu} \mathrm{K} \alpha$ radiation. Ferrite content measurement was carried out using OLYMPUS optical microscope equipped with Clemex Image Analysis program. The surface roughness analysis was performed via a BRUKER AFM Q-SCOPE 250/400 brand device at a scanning size of $40 \mu \mathrm{m}$ and a scan rate of $0.5 \mathrm{~Hz}$ in tapping mode.

\subsection{Toxicology studies methods, MTT (Thiazolyl Blue Tetrazolium Bromide)}

The Thiazolyl Blue Tetrazolium Bromide (MTT) assay is a colorimetric assay for measures the metabolic activity levels of cell mitochondria. It can also be used to measure cytotoxicity or potential of proliferation medicinal agents and toxic materials [26]. Active metabolism of the viable cells seem a purple colored formazan crystals. The crystallization and cell viability is directly proportionate to each other, therefore as much crystallization there is means how much the cells are viable.

\subsection{Cell culture studies}

Cytotoxicity is metabolic activities for cellular function differentiations, which are mainly related to changes in intracellular processes such as apoptosis, cell viability or biocompatibilities [27]. In vitro cell-based assays have been improved to rapidly determine the cytotoxic activity of several compounds or materials [28]. The L929 cells tubes were removed from cryobank $\left(-196{ }^{\circ} \mathrm{C}\right.$ Nitrogen tank) at $37^{\circ} \mathrm{C}$ in water in the beaker. $4 \mathrm{ml}$ of $10 \% \mathrm{FBS}, \mathrm{DMEM} / \mathrm{F}-$ 12 medium were added onto cells. Then centrifuged for 5 minutes at $1000 \mathrm{rpm}$. After centrifugation, supernatant was removed, pellets were suspended. To determine cell viability by thoma slide, $20 \mathrm{~mL}$ of cell suspension was mixed with $20 \mathrm{~mL}$ of Trypan Blue and the cells were counted. These cells are routinely transferred into a small flask. The samples were sterilized under $170{ }^{\circ} \mathrm{C}$ for 90 minutes in a pasteur oven.

Then DMEM/F-12 (Thermofisher Scientific 31331028) medium was added on them and samples were left for incubation. The materials were incubated at $37^{\circ} \mathrm{C}$ for 7 days. After this, a sample medium has was taken out of the tubes. The samples were named as supernatants after the interaction with the materials. Approximately 10000 cells per well were seeded 96-well plates, each sample were repeated approximately 8 times for the statistic analysis, and $100 \mathrm{~mL}$ of DMEMF/12 were added on the cells. As a result of fully covering period of cells on the wells, the medium was removed, and the cells were exposed to the culture medium containing supernatants of the base metal and laser welded metal for additional 24 hours. To be able to make a comparison, a control group was formed by putting mediums that did not have any supernatants.

Following the incubation, the MTT protocol has been applied to determine the cell viability. $10 \mathrm{ml}$ of MTT solution $(10 \mathrm{mg} / \mathrm{ml})$ was prepared and, put in each well after being filtered with $0.45 \mu \mathrm{l}$ filters and incubated for 4 hours at $37^{\circ} \mathrm{C}$ and then the crystallization was observed under the microscope. $100 \mu \mathrm{l}$ of Dimethyl sulfoxide (DMSO SIGMA D2438) were added to each well for the dissolution of the formazan crystals formed on the cells and the absorbance was measured in $570 \mathrm{~nm}$ by a ELISA spectrophotometer reader and the results were obtained. At the end of MTT method, crystallization was observed microscopically in the cells.

\subsection{Statistical analysis}

In multiple comparisons, the Tukey test has been applied as a post-hoc test for the ANOVA one-way analysis of variance on the GraphPad statistics software. In the assessment of the results, the significance levels of $\mathrm{p}<0.001, \mathrm{p}<0.01$ and $\mathrm{p}<0.05$ have been used as a basis.

\section{RESULTS AND DISCUSSION}

\subsection{Macro- and microstructural examinations}

The macro and microstructure examination of the base metal, the heat affected zone (HAZ) and the weld metal of the AISI 2205 duplex stainless steel joined by $\mathrm{CO}_{2}$ laser beam welding used in the study and the results are shown in Fig. 1. 


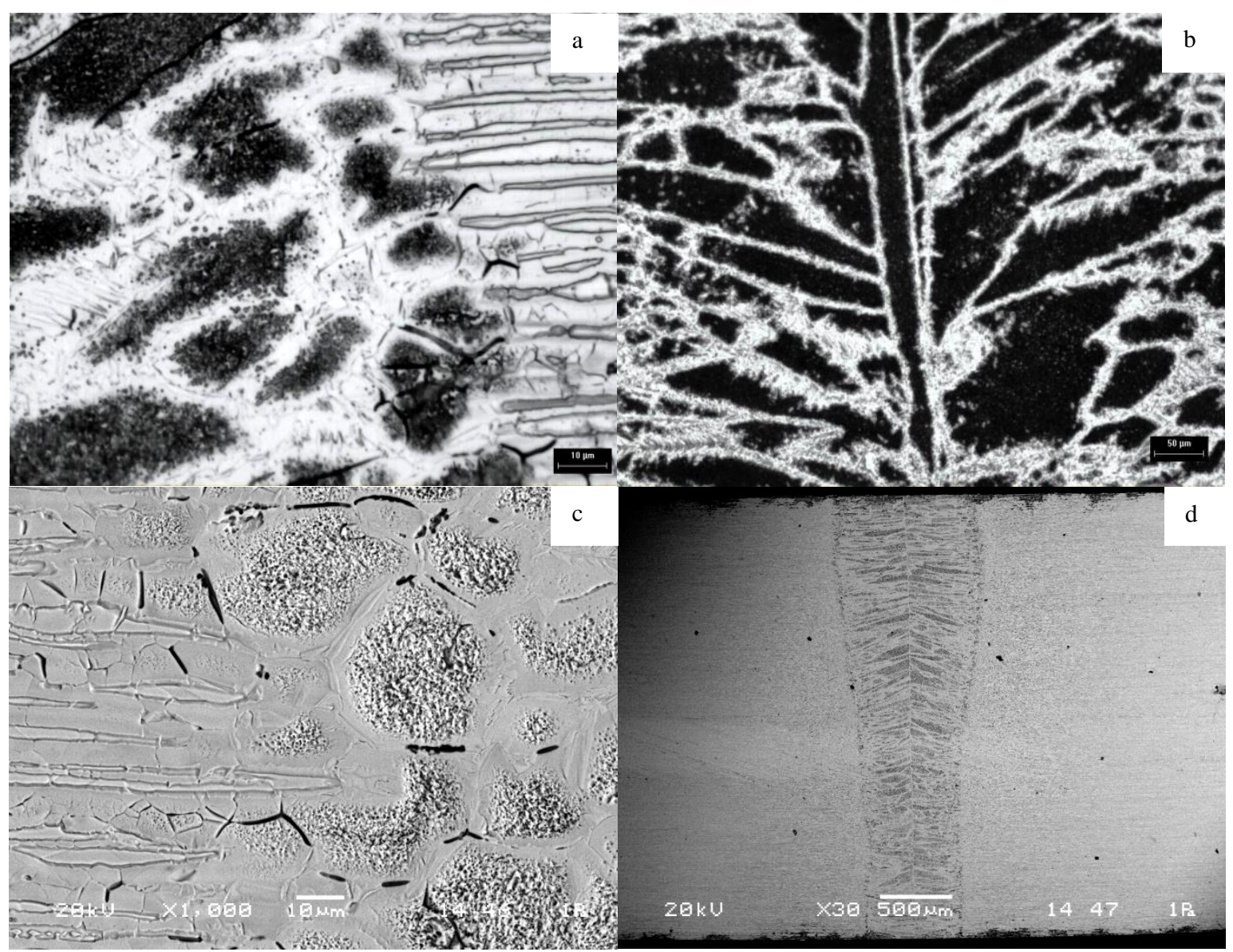

Fig. 1. a-microstructure image of HAZ; b - weld metal; c-SEM image of HAZ; d-macrostructure of laser welded sample

As can be seen in Figure 1b, the weld metal structure of AISI 2205 stainless steel as it was provided consists of ferrite phase $(70 \%)$ and austenite phase $(30 \%)$ and it has almost fully ferritic structure with some precipitation of austenite decorate to the grain boundaries. The light colored grains in the structure indicate the austenite phase while the dark colored ones indicate the ferrite phase. As it is known, the high tensile strength and stress corrosion resistance of duplex stainless steel results from the delta ferrite phase in

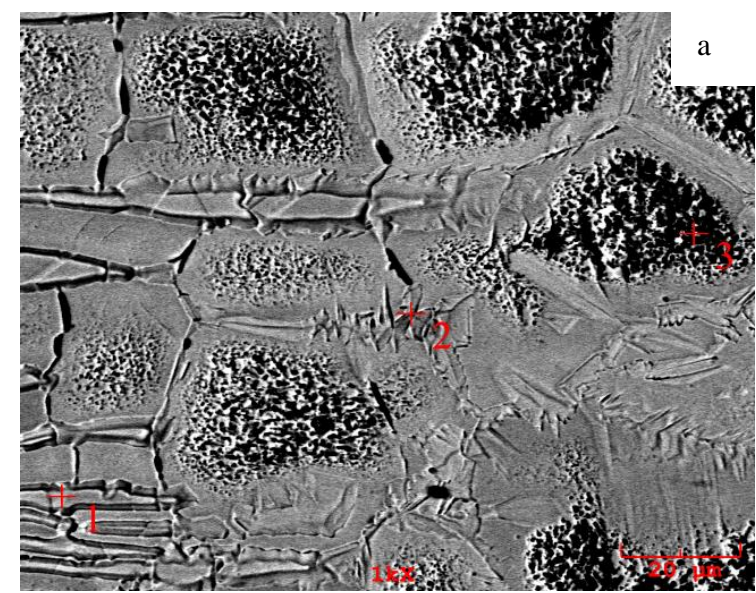

its structure while its toughness and general corrosion resistance results from the austenite phase in its structure [16]. The micrographic examination shows that the extension of the heat affected zone is negligible (Fig. $1 \mathrm{a}, \mathrm{c}$, and d). Formation of a very narrow heat affected zone is an expected result since low heat input, which is a characteristic of laser beam welding, causes fast cooling [16].

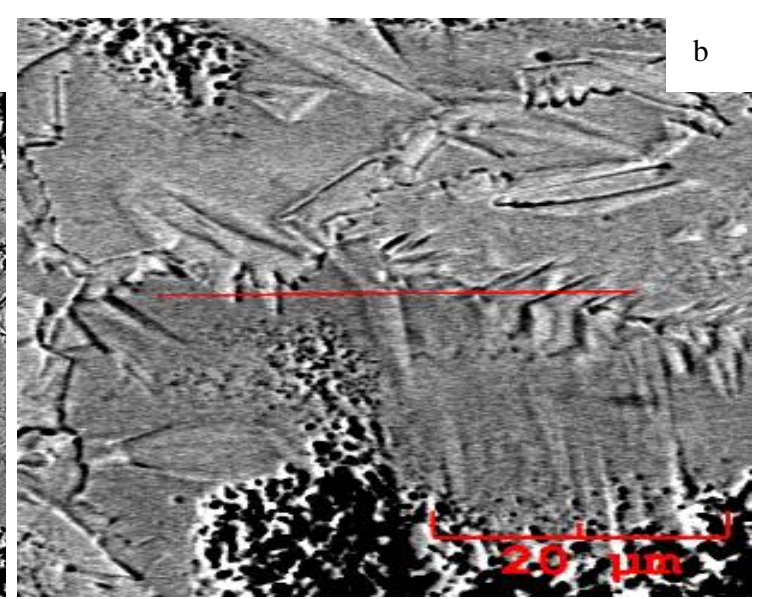

\begin{tabular}{|l|c|c|c|c|}
\hline EDS analysis (wt.\%) & $\mathrm{Cr}$ & $\mathrm{Ni}$ & $\mathrm{Mo}$ & $\mathrm{Fe}$ \\
\hline Point number + 1 base metal & 23.40 & 4.44 & 3.14 & 64.59 \\
\hline Point number + 2 HAZ & 24.65 & 4.82 & 2.38 & 66.17 \\
\hline Point number + 3 weld metal & 21.36 & 5.35 & 3.23 & 63.10 \\
\hline Elemental mapping analysis of the weld metal & 23.28 & 5.17 & 3.61 & 64.78 \\
\hline
\end{tabular}

Fig. 2. a-EDS point elemental analysis; $b$ - elemental mapping analysis results from the laser welded joint 
EDS analysis of the base metal, HAZ and the weld metal and elemental mapping analysis in the weld metal of the laser welded joint was made and the results can be seen in Fig. 2. When the results of the EDS and elemental mapping analysis that are demonstrated in Fig. 2 are compared to the spectral analysis results (Table 1), nonoccurence of significant element loss was idendified with analyses carried out from welded sample.

Base metal and laser welded sample have been examined through the XRD method, and the results are demonstrated in Fig. 3. When the XRD pattern is examined, we can see that there are peaks, which indicate the presence of austenite and ferrite phases. However, no peaks that expressed the formation of second phase precipitations in HAZ and weld metal were detected in the XRD pattern. When there is not enough time due to fast cooling, which results from low heat input and high energy density, carbide formations cannot be expected to occur [16].

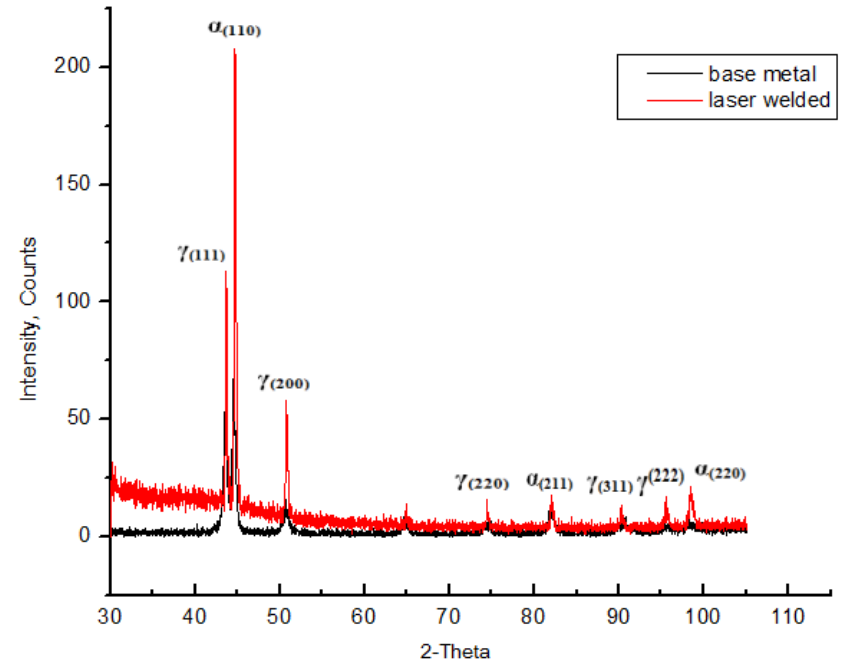

Fig. 3. XRD analysis from weld zone and base metal

\subsection{Surface analysis of base metal and welding seam}

Surface roughness is an important parameter for most applications [12]. Characterization of material surface roughness enables us to idendify which application areas are suitable for that material [12]. SEM images of base metal and welding seam surface after polishing with sandpaper are shown in Fig. 4.

Average surface roughness $\left(\mathrm{R}_{\mathrm{a}}\right)$ values were determined with AFM analysis performed on base metal surface and welding seam surface and and the obtained surface topography images are shown in Fig. 5 . $\mathrm{R}_{\mathrm{a}}$ value measured on base metal surface was found to be $21.1 \mathrm{~nm}, \mathrm{R}_{\mathrm{a}}$ value measured on welding seam surface was found to be $23.5 \mathrm{~nm}$. Even though surfaces of base metal and laser welded sample were prepared in the same conditions, surface roughness on welding seam surface of laser welded sample showed a small increase. Reasons for increase in roughness value are effect of heat input transmitted to weld zone to welding seam surface texture, thickness of thin chromium-oxide layer surrounding surface and physical properties of chromium-oxide layer [12]. It can be expected that difference in surface roughness values of base metal and welding seam surface has an effect on cell viability.

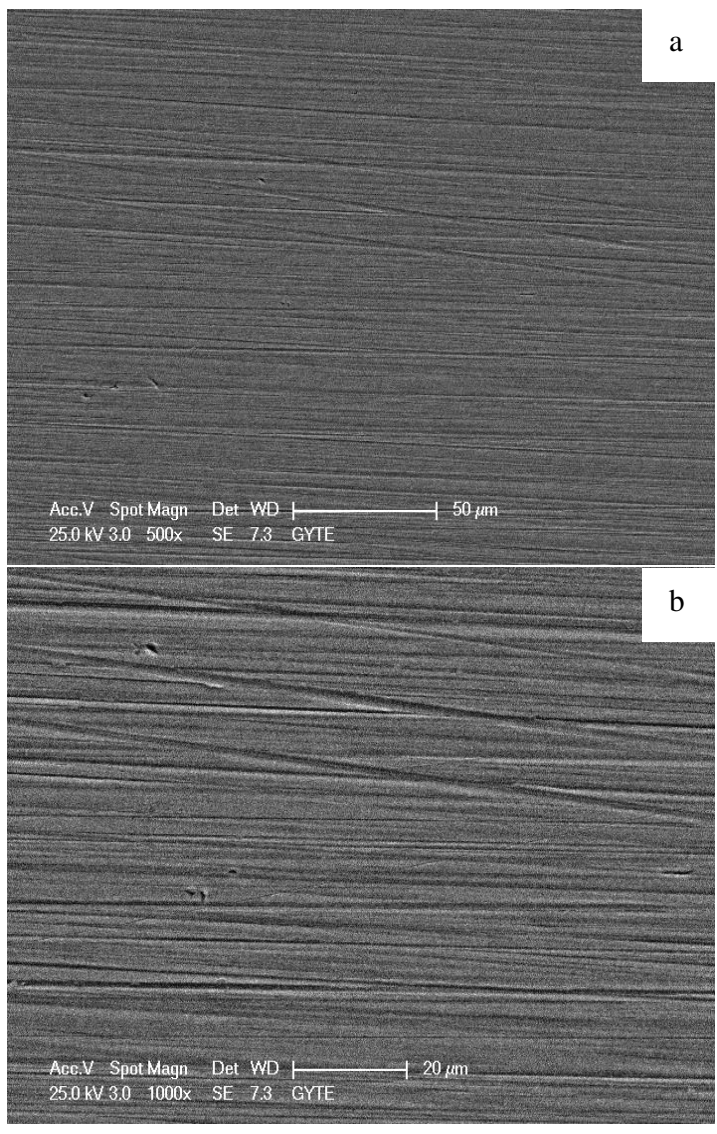

Fig. 4. SEM image of the samples before AFM characterization: $a$-base metal surface; $b$-welding seam surface of the laser welded sample
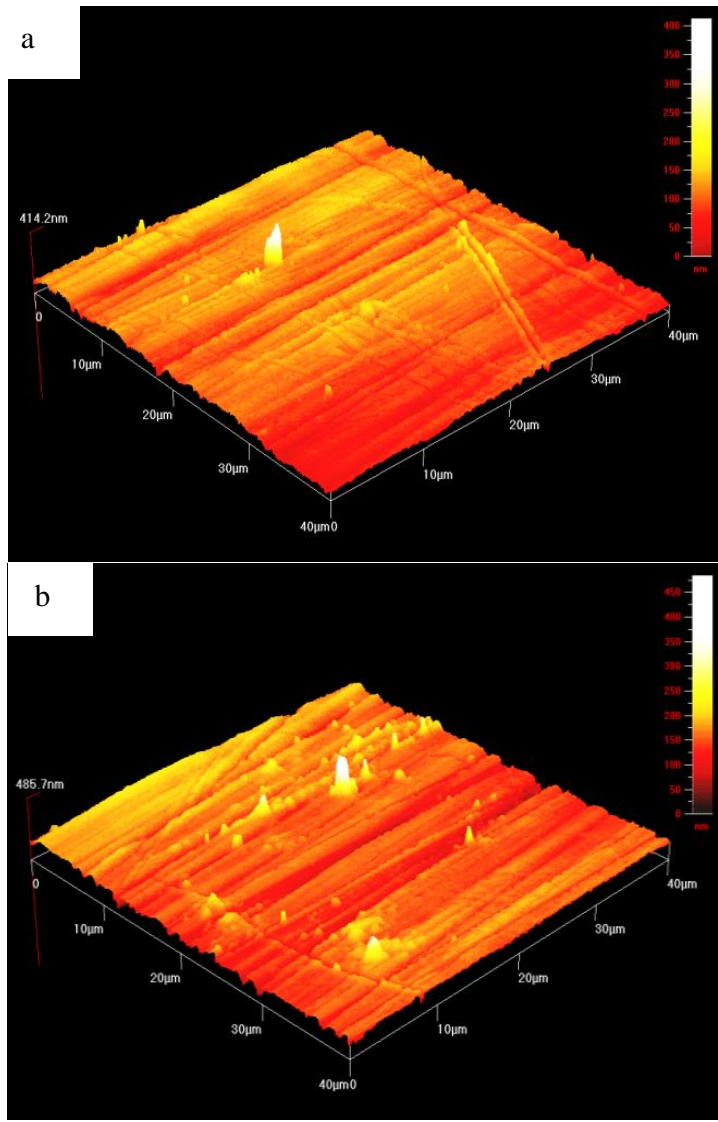

Fig. 5. AFM images: a-base metal surface; $b$ - welding seam surface 


\subsection{Cell studies}

The effect of $\mathrm{CO}_{2}$ laser beam welding method applied to AISI 2205 duplex stainless steel on the viability of the fibroblast cells was studied by placing the base metal and laser welded samples directly in the cell culture medium for particular periods. MTT results are given in Fig. 6 and Fig. 7.

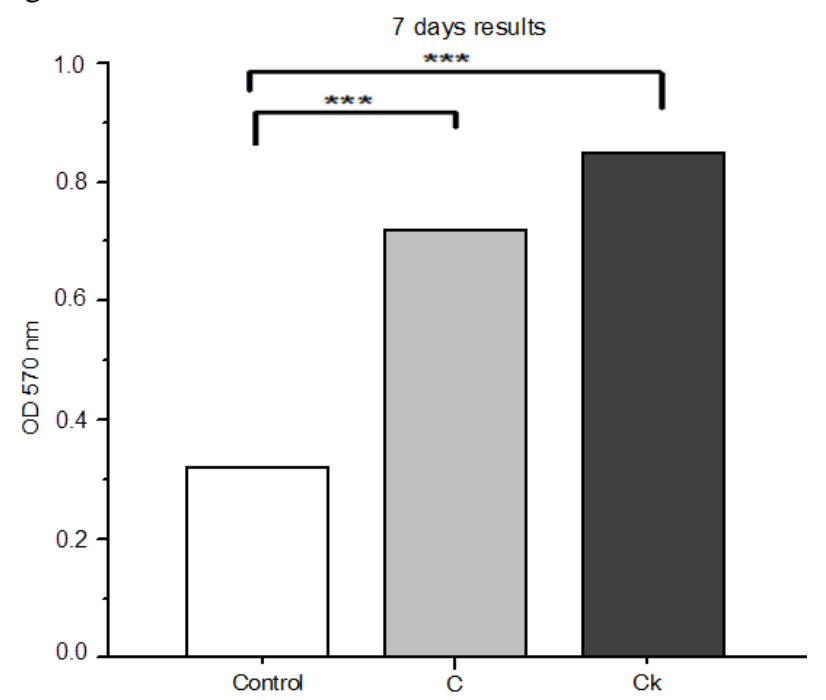

Fig. 6. The results of the MTT which is applied as a result of L929 cell culture and the samples: $\mathrm{C}-\mathrm{Control}, \mathrm{C}$-base metal, $\mathrm{Ck}$ - laser welded sample

The base metal and the laser welded sample show better cell viability effect when compared to the control group (Fig. 6 and Fig. 7) As a result of the direct interaction of the L929 cell culture and the control, base metal and laser welded sample, while an increase in the cell proliferation of base metal and the laser welded sample has been observed in comparison with the control group ( $p<0.001)$. Consequently, the interaction of the samples of supernatants and L929 cell culture's viability were compared with the control group of viability. It was an affect that increased the cell proliferation with supernatant proceeding $(\mathrm{p}<0.001)$. On the other hand results have shown us that supernatants from the laser welded sample affected cell viability more than the base metal by increasing cell proliferation. The results were statistically analyzed and found significant.
When the results regarding the 2205 duplex stainless steel base metal and laser welded sample are studied, after the 7 days, the effect of the supernatant samples obtained from the mediums in which the samples were kept on the cell viability was higher for laser welded sample when compared with the base metal. In laser welding, weld metal has finer grains and therefore, larger grain boundary due to high solidification rate. The grain boundaries have higher energy than inside the grains [14,29]. Therefore, this excessive energy in grain boundary combined with high ferrite phase content $(70 \%)$ and austenite phase (30\%) and it has almost fully ferritic structure with some precipitation of austenite decorate to the grain boundaries. Weld metal is considered for the reason of the denser cells at the beginning of the MTT process. However, the grain boundaries are more chemically reactive than the grains themselves as a consequence of this grain boundary energy [14, 29] and the rapid ion exchange along the grain boundaries can be responsible for less dense cells in laser welded sample compared with base metal at the end of the long period MTT process. There are some studies indicating that surface roughness and surface chemistry are directly associated with cell adhesion, growth and proliferation [30]. As mentioned in previous sections of text, surface roughness value on welding seam was found to be higher than base metal. For this reason, high surface roughness is thought to increase cell viability.

\section{CONCLUSIONS}

According to the results acquired, the interaction of the $\mathrm{CO}_{2}$ laser beam welded AISI 2205 duplex stainless steel sample and base metal with the L929 fibroblast cells which were connective tissue elements were studied under in vitro conditions.

The findings obtained can be summarized as follows:

1. The low heat input and high cooling rate of laser beam welding method had an effect on the microstructure and morphology of the weld metal. In addition, ferriteaustenite equilibrium of the weld metal and the HAZ differed from that of the base metal as to be in favor of ferrite phase $(70 \%)$, also, the low heat input caused a very narrow HAZ.
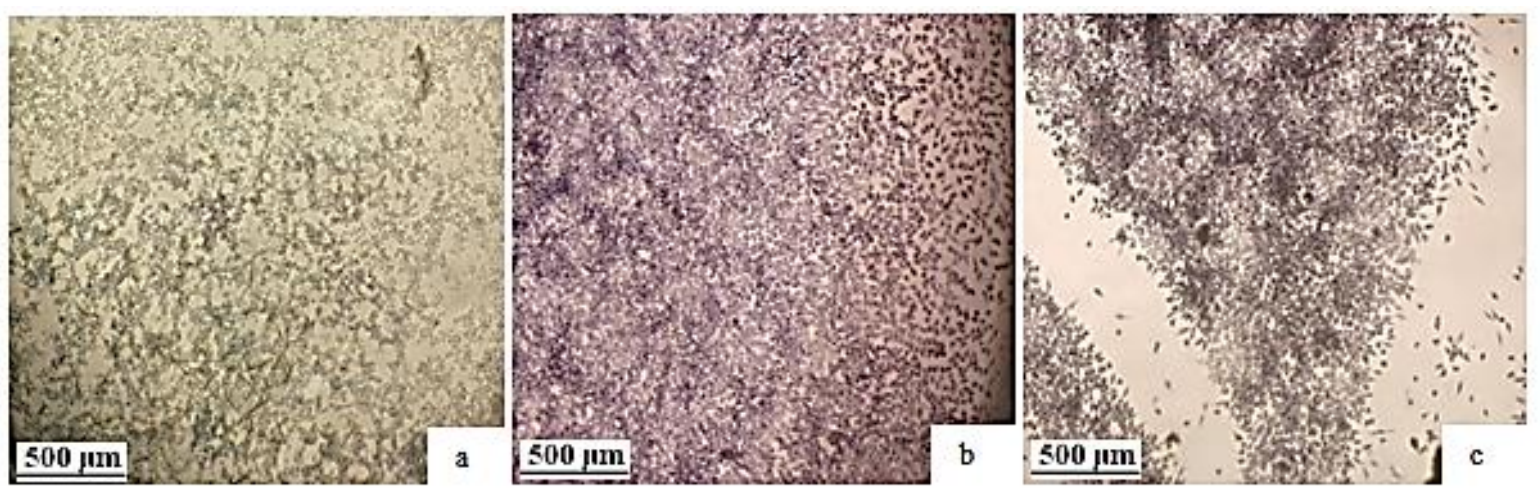

Fig. 7. Formazan crystal formation after 7 days MTT $(10 \times)$ : a-L929 control has been incubated only with the DMEMF12 culture medium. The control cells and the density of the formazan crystals which indicate the viability are scarcer than the cells shown in figures b and c. The post MTT image of the L929 cell culture which has been incubated with the supernatant taken from the medium in which the base metal was kept for 7 days. Density of the cells and formazan crystals has been observed to be higher than the control 
2. No secondary phases were detected in the HAZ and weld metal. In this context, the weld zone could not be assessed for its potential performance on the effect on the viability of the cells apart from secondary phase precipitations.

3. When the data taken after the 7 days were evaluated, the effect of the laser welded sample on the cell viability was greater than that of the base metal sample. When base metal $\mathrm{C}$ and laser welded $\mathrm{Ck}$ sample were compared with control group, $\mathrm{C}$ sample had a cell viability increase ratio of $234.7 \%$ while $\mathrm{Ck}$ sample had a cell viability ratio of 276.8 . It is thought that higher grain boundary energy, the presence of high delta ferrite phase content $(70 \%)$ in weld metal and higher surface energy of weld zone due to weld thermal cycle can be reason of denser cells at the beginning of the process. Cell viability might have been affected by the weld thermal cycle and chromium oxide film characteristics on the weld seam surface. Also, in our opinion, trace elements released by the material into the medium have an effect on increasing cell viability thus resulting in cell proliferation.

4. Surface roughness value on laser welding seam was determined to be higher than base metal, reason for increase in roughness value is effect of heat input transmitted to weld zone to welding seam surface texture. Because of surface roughness value on welding seam is higher than base metal, cell attachment and proliferation can be said to occur more in laser welded sample than base metal

\section{REFERENCES}

1. Wang, S., Ma, Q., Li, Y. Characterization of Microstructure, Mechanical Properties and Corrosion Resistance of Dissimilar Welded Joint Between 2205 Duplex Stainless Steel and 16MnR Materials and Design 32 (2) 2011: pp. $831-837$. https://doi.org/10.1016/j.matdes.2010.07.012

2. Diaz, J.J., Rodriguez, M., Nieto, G., Fresno, D. Comparative Analysis of TIG Welding Distortions Between Austenitic and Duplex Stainless Steels by FEM Applied Thermal Engineering 30 (16) 2010: pp. 2448-2459. https://doi.org/10.1016/j.applthermaleng.2010.06.016

3. Llorca-Isern, N., López-Luque, H., López-Jiménez, I., Biezma M.V. Identification of Sigma and Chi Phases in Duplex Stainless Steels Materials Characterization 112 2016: pp. 20-29.

https://doi.org/10.1016/j.matchar.2015.12.004

4. Varol, I., Lippold, J.C., Baeslack, W.A. Characterization of Weld Solidification Cracking in a Duplex Stainless Steel Materials Characterization 39 (2-5) 1997: pp. 555-573. https://doi.org/10.1016/S1044-5803(97)00144-7

5. Martin, G., Yerra, S.K., Brechet, Y., Chehab, B.A. A Macro- and Micromechanics Investigation of Hot Cracking in Duplex Steels Acta Materialia $60(11)$ 2012: pp. 4646-4660.

https://doi.org/10.1016/j.actamat.2012.03.040

6. Garcia, R.L., Portero, M.J., Anton, J. Corrosion Behaviour of Sensitized and Unsensitized Alloy 900 (UNS 1.4462) in Concentrated Aqueous Lithium Bromide Solutions at Different Temperatures Corrosion Science 52 (3) 2010: pp. $950-959$.

https://doi.org/10.1016/j.corsci.2009.11.018
7. Sieurin, H., Sandstrom, R. Fracture Toughness of a Welded Duplex Stainless Steel Engineering Fracture Mechanics 73 (4) 2006: pp. 377-390. https://doi.org/10.1016/j.engfracmech.2005.03.009

8. Köse, C. Weldability of 5754 Aluminum Alloy by Using Pulsed Nd:YAG Micro Scale Laser Materials Testing $58(11-12)$ 2016: pp. $963-969$. https://doi.org/10.3139/120.110947

9. Köse, C., Kaçar, R. The Effect of Preheat \& Post Weld Heat Treatment on the Laser Weldability of AISI 420 Martensitic Stainless Steel Materials \& Design 64 2014: p. 221-226. https://doi.org/10.1016/j.matdes.2014.07.044

10. Köse, C., Karaca, E. Robotic Nd:YAG Fiber Laser Welding of Ti-6Al-4V Alloy Metals 7 (6) 2017: pp. 211-221. https://doi.org/10.3390/met7060221

11. Köse, C., Kaçar, R. Investigation of the Mechanical and Microstructural Properties of Laser Beam Welded AISI 2205 Duplex Stainless Steel Technological Applied Sciences 11 (4) 2016: pp. 99-109. https://doi.org/10.12739/NWSA.2016.11.4.2A0100

12. Köse, C. An Investigation of the Surface Characterization of Laser Surface Remelted and Laser Beam Welded AISI 316L Stainless Steel International Journal of Electrochemical Science 11 2016: pp. 3542-3554. https://doi.org/10.20964/110433

13. Köse, C., Kaçar, R. In Vitro Bioactivity and Corrosion Properties of Laser Beam Welded Medical Grade AISI 316L Stainless Steel in Simulated Body Fluid International Journal of Electrochemical Science 11 2016: pp. 2762-2777. https://doi.org/10.20964/110402762

14. Köse, C., Kaçar, R., Zorba, A.P., Bağırova, M., Allahverdiyev, M.A. The Effect of $\mathrm{CO}_{2}$ Laser Beam Welded AISI 316L Austenitic Stainless Steel on the Viability of Fibroblast Cells, in vitro Materials Science and Engineering: C 60 2016: pp. 211-218. https://doi.org/10.1016/j.msec.2015.11.035

15. Taskin, M., Caligulu, U., Turkmen, M. X-Ray Tests of AISI 430 and 304 Stainless Steels and AISI 1010 Low Carbon Steel Welded by $\mathrm{CO}_{2}$ Laser Beam Welding Materials Testing $53(11-12)$ 2011: pp. 741-747. https://doi.org/10.3139/120.110283

16. Köse, C., Kaçar, R. Mechanical Properties of Laser Welded 2205 Duplex Stainless Steel Materials Testing $56(10)$ 2014: pp. $779-785$ https://doi.org/10.3139/120.110632

17. Kocijan, A., Conradi, M., Schön, P.M. Austenitic and Duplex Stainless Steels in Simulated Physiological Solution Characterized by Electrochemical and X-Ray Photoelectron Spectroscopy Studies J Biomed Mater Res Part B 100 (3) 2012: pp. 799-807. https://doi.org/10.1002/jbm.b.32513

18. Finšgar, M., Fassbender, S., Hirth, S., Milošev, I. Electrochemical and XPS Study of Polyethyleneimines of Different Molecular Sizes as Corrosion Inhibitors for AISI 430 Stainless Steel in Near-Neutral Chloride Media Materials Chemistry and Physics 116 (1) 2009: pp. 198-206. https://doi.org/10.1016/j.matchemphys.2009.03.010

19. Eliades, T., Athanasios, E. In Vivo Aging of Orthodontic Alloy: Implications for Corrosion Potential, Nickel Release and Biocompatibility Angle Orthodontic 72 (3) 2002: pp. 222-237. https://doi.org/10.1043/00033219(2002)072<0222:IVAOOA >2.0.CO;2 
20. Kocijan, A., Conradi, M. The Corrosion Behaviour of Austenitic and Duplex Stainless Steel in Artificial body fluids Materials and Technology 44 (1) 2010: pp. 21-24.

21. Sathiyanarayanan, S., Marikkannu, C., Srinivasan, B., Muthupandi, V. Corrosion Behaviour of Ti6Al4V and Duplex Stainless Steel in Synthetic Biofluids Anti-Corrosion Methods and Materials 49 (1) 2002: pp. 33-37.

22. Capello, E., Chiarello, P., Previtali, B., Vedani, M. Laser Welding and Surface Treatment of a $22 \mathrm{Cr} / 5 \mathrm{Ni} / 3 \mathrm{Mo}$ Duplex Stainless Steel Materials Science and Engineering: A $351(1-2)$ 2003: pp. 334-343.

https://doi.org/10.1016/S0921-5093(02)00841-9

23. Bachmann, M., Kunze, R., Avilov, V. Finite Element Modeling of an Alternating Current Electromagnetic Weld Pool Support in Full Penetration Laser Beam Welding of Thick Duplex Stainless Steel Plates Journal of Laser Applications 28 (2) 2016: pp. 1-9. https://doi.org/10.2351/1.4943906

24. Lai, R., Cai, Y., Wu, Y., Li, F., Hua, X. Influence of Absorbed Nitrogen on Microstructure and Corrosion Resistance of 2205 Duplex Stainless Steel Joint Processed by Fiber Laser Welding Journals of Materials Processing Technology 231 2016: pp. 397-405. https://doi.org/10.1016/j.jmatprotec.2016.01.016

25. Mockers, O., Deroze, D., Camps, J. Cytotoxicity of Orthodontic Bands, Brackets and Archwires in vitro Dental Materials 18 (4) 2002: pp. 311-317.

\section{https://doi.org/10.1016/S0109-5641(01)00055-0}

26. Hussain, R.F, Nouri, A.M.E., Oliver, R.T.D. A New Approach for Measurement of Cytotoxicity Using Colorimetric Assay Journal of Immunological Methods 160 1993: pp. 89-96. https://doi.org/10.1016/0022-1759(93)90012-V

27. Freshney, R.I. Culture of Animal Cells: A Manual of Basic Technique and Specialized Applications. 6th ed. John Wiley \& Sons, Hoboken, NJ, 2010: pp. 365-381. https://doi.org/10.1002/9780470649367

28. Jacoby, L.S, Rodrigues Junior, V.D.S., Campos, M.M., Macedo de Menezes, L. Cytotoxic Outcomes of Orthodontic Bands with and Without Silver Solder in Different Cell Lineages American Journal of Orthodontics and Dentofacial Orthopedics 151 (5) 2017: pp. 957-963. https://doi.org/10.1016/j.ajodo.2016.10.030

29. Callister, W.D. Materials Science and Engineering and Introduction, Third edition A John Wiley \& Sons. INC, New York, USA, 1994: pp. 66-74.

30. Zareidoost, A., $\quad$ Yousefpour, M., $\quad$ Ghaseme, B., Amanzadeh, A. The Relationship of Surface Roughness and Cell Response of Chemical Surface Modification of Titanium Journal of Materials Science. Materials in Medicine 23 (6) 2012: pp. $1-17$.

https://doi.org/10.1007/s10856-012-4611-9 